\title{
MANAGEMENT OF PARTHENIUM HYSTEROPHORUS USING SUPPRESSIVE PLANTS
}

*Sadiq Ali and Ijaz Ahmad Khan

Department of Weed Science, The University of Agriculture, Peshawar- Pakistan

*Correspondence author: sadiq.agri@gmail.com

Received: $1^{\text {st }}$ August $2016 \quad$ Revised: 20 $0^{\text {th }}$ April $2017 \quad$ Accepted: 20 $0^{\text {th }}$ July 2017

\begin{abstract}
Parthenium hysterophorus; an invasive, noxious weed creates problem in field crops, pastures, waste lands and affects the fodder crops in Khyber Pakhtunkhwa, province of Pakistan. P. hysterophorus secretes allelochemicals to suppress the growth of neighboring plants. However, some crops have the ability to suppress the growth of numerous weeds. For this purpose field experiments were conducted at two different locations having variable climatic conditions to manage $P$. hysterophorus through some suppressive plants. The study revealed that sorghum, buffel grass, millet and maize showed good suppressive ability of $P$. hysterophorus weed biomass as compared to control which produced higher biomass at both field sites. However, at lower altitude site i.e Swabi, the highest $P$. hysterophorus dry biomass $\left(340.45 \mathrm{~g} \mathrm{~m}^{-2}\right)$ was recorded in moth bean plots, while at high altitude site (Haripur), the maximum $P$. hysterophorus dry biomass $\left(384.80 \mathrm{~g} \mathrm{~m}^{-2}\right)$ was found in mung bean plots. Moreover, at both sites, the sorghum, buffel grass, millet and maize plants reduced the $P$. hysterophorus growth up to $84.0 \%, 79.0 \%, 70.2 \%$ and $67.5 \%$, respectively. Whereas mung bean and moth bean were found poor suppressive plants to reduce the growth of $P$. hysterophorus. Furthermore, the competitive ability of $P$. hysterophorus with other plants were climatic condition dependent as this weed poorly compete with the tested plants in the warmer climatic condition at Swabi site than the cooler area at Haripur site. Thus, it is to concluded that sorghum and buffel grass are better option to manage $P$. hysterophorus in the fields infested with invasive P. hysterophorus.
\end{abstract}

Keywords: Parthenium, suppressive fodder plants, competition

\section{INTRODUCTION}

Parthenium weed (Parthenium hysterophorus L.) is an annual alien invasive species in Pakistan belonging to the Asteraceae family, it is commonly known as carrot grass, bitter weed and star weed. Parthenium weed is a native to the Caribbean region but has been spread unintentionally into many countries (Parsons \& Cuthbertson 1992; Adkins et at. 1996). This weed was first spotted in the Punjab Province of Pakistan, probably introduced from India 20 years ago and it has rapidly spread into the northern and central regions of Pakistan (Shabbir et al. 2012). Parthenium weed can grow under ecological conditions with high seed production and a fast spreading ability. Its height reached up to $2 \mathrm{~m}$ when growing in good soil and capable of flowering within 4 to 6 weeks of germination (Navie et al. 1996). It is well adapted in semiarid environment because of its large soil seed bank and fast germination. It releases chemicals that affect the growth of neighboring plants. It also reduces the 
agricultural crop production up to $40 \%$ and reduces fodder production by $90 \%$ (Khosla \& Sobti 1979). Parthenium weed causes severe human health problems as well as agricultural losses and causes allergy in respiratory system, contact dermatitis and mutagenicity in humans and livestock.

In Pakistan, parthenium weed has been recorded as the worst weed along roadsides, on wastelands and in certain summer cropping and perennial grass land regions, it negatively affects agricultural production and reduces native plant biodiversity (Riaz and Javaid 2011; Shabbir et al. 2012). High cost of herbicides, resistance of weeds to herbicides and environmental pollution instigates alternative methods of weed control including parthenium weed management. In rangelands some native grass species, such as cogon grass (Imperata cylindrica L. Beauv), halfa grass (Desmostachya bipinnata L. Stapf.), blue-stem (Dichanthium annulatum Forssk. Stapf.), slender buffel grass (Cenchrus pennisetiformis Hochst. \& Steud.) and Johnson grass (Sorghum halepense L. Pers.) have all been reported to be good at suppressing parthenium weed growth in Pakistan (Anjum and Bajwa 2005; Javaid et al. 2005). Parthenium weed infestations were found in many cultivated crops (Shabbir and Bajwa 2006). Two cultivated crops, such as sorghum (Sorghum bicolor
L.) and maize (Zea mays L.) have also been shown to significantly suppress growth of parthenium weed in the field (Singh 1993). Less fruiting of leguminous crops and chlorophyll of crop plants reduction were observed in parthenium weed infested fields (Lakshmi and Srinivas 2007). Best management can be achieved by using pasture grass to provide best competition against this weed. Some plants have characteristic such as faster germination, height, secrete chemicals and form canopies above the ground, which suppressed the growth of parthenium weed (Williams and Groves 1980; Tamado et al. 2002). Cultural control was shown very successful tool used for maintaining the naturally existing plant biodiversity and sowing selected suppressive plant species into the infested areas, for the management of parthenium weed (Wahab 2005).

Keeping under consideration the
aggressiveness of parthenium weed
throughout Pakistan, field trials were
conducted with the objectives to figure out
the effect of parthenium weed on the dry
biomass production of selected plants. In
order to observe the impact of selected
plants upon the growth of parthenium weed
and their fodder production potential at two
different areas of Khyber Pakhtunkhwa
districts Swabi and Haripur having different
climatic conditions.
climatic conditions. 


\section{MATERIALS AND METHODS}

\section{Experimental Sites}

For the conduct of this research two areas were selected on the basis of parthenium weed infestation and differences in climatic condition. The first field site is located at district Swabi of Khyber Pakhtunkhwa Province (N 34 ${ }^{0} 7^{\prime} 12^{\prime \prime}, 72^{\circ}$ $28^{\prime} 20^{\prime \prime}$ E) and having a warmer climatic condition. The mean annual and summer precipitation of Swabi is 639 and $137 \mathrm{~mm}$, while the mean annual and summer day/night temperature is 22.2/17.1 and $34.5 / 24.4{ }^{\circ} \mathrm{C}$, respectively. The soil of that area is gray brown sandy loam ( $\mathrm{pH} 7.64)$.

The second field site was at district Haripur, Khyber Pakhtunkhwa Province (N 25 48' 30", $88^{\circ}$ 08' 30" E) having a temperate climatic condition with a mean annual and summer precipitation of 832 and $701 \mathrm{~mm}$, and a mean annual and summer day/night temperature of $21.5 / 10.1$ and $32.0 / 21.3^{\circ} \mathrm{C}$ respectively. The soil of that area was gray sandy clay loam ( $\mathrm{pH}$ 6.9). Zygogramma bicolorata was the only biological control agent of parthenium weed was present at both the studied areas. The reason behind the selection of these areas were to check the performance of the competitive fodder crops against parthenium weed under different climatic conditions because the Swabi area has warm climate, while the Haripur area is the cooler one. Moreover, the Swabi area fields are irrigated while in the Haripur area fields are rainfed.

\section{Field Preperation}

Each field site was ploughed twice to a depth of $15 \mathrm{~cm}$ using a cultivator mounted upon a tractor and then hand raked to remove surface trash and to create a smooth seed bed. Twenty eight plots (each $5 \mathrm{~m} \mathrm{x}$ $3 \mathrm{~m}$ ) were marked with wooden pegs. Irrigation were applied to both field sites during the first 10 days period after seeding to help boost germination and seedling establishment and no fertilizer was applied. All plants that emerged, other than those of the test species sown and $P$. hysterophorus were removed manually. The trials were run for a period of 145 days; from early June to October, 2013.

\section{Test Species Selection}

Six species were selected for both field sites which included Sorghum bicolor L. (sorghum), Zea mays L. (maize), Cenchrus ciliaris (buffel grass), Pennisetum glaucum L. (millet), Vigna radiata L. Wilczek.) (mung bean) and Vigna aconitifolia L. (moth bean) identified previously as being suppressive to the growth of Parthenium hysterophorus under field conditions (Singh 1993) and their local vigorous growth and better performances. The seeds of these species were obtained from the New Developmental Farm, The University of Agriculture, Peshawar and Pakistan Forest Institute, Peshawar; having $>80 \%$ viability. At both field sites the sowing of pre weighed seed using standard seeding rates (as recommended by the New Developmental Farm, The University of Agriculture and Pakistan Forest Institute) was undertaken in 
early June, 2013. To achieve an even sowing rate, seed of each test species was evenly spread over the assigned plots by hand. The seed was then pressed into the soil surface with a $60 \mathrm{~kg}$ steel roller to ensure good seed soil contact to promote rapid and uniform seed germination as well as limit predation by ants. The $P$. hysterophorus population at each field site was established from the large soil seed bank.

\section{Experimental Design And Data Collection}

Both of the field sites were established using a Randomized Complete Block Design with split plot arrangement. At each of the two field sites, there were six test species each with four replications and the ambient growth of $P$. hysterophorus which was treated as a check. To determine dry shoot biomass at each field site, a quadrat $\left(0.50 \mathrm{~m}^{2}\right)$ was randomly placed five times into each of the replicated plots and all plants of either $P$. hysterophorus or the test species cut at soil level. All cut samples were separated into $P$. hysterophorus or test species, then dried $\left(72 \mathrm{~h}\right.$ at $\left.70 \pm 2{ }^{\circ} \mathrm{C}\right)$, and weighed.

\section{Statistical Analysis}

A two way analysis of variance was run on the shoot dry biomass data in order to determine the suppressive ability of the test species against $P$. hysterophorus and also their fodder production and statistically significant means $(\mathrm{P}<0.05)$ were subjected to LSD test for separating the means (Steel and Torrie, 1980).

\section{RESULT AND DISCUSSIONS}

\section{Competative Plants Dry Biomass $\left(\mathrm{g} \mathrm{m}^{-2}\right)$}

The analysis of the data revealed that $P$. hysterophorus growth reduction was noted for all the competitive plants such as sorghum, buffel grass, millet, maize, mung bean and moth bean compared to check or control. The locations means showed that both the locations have significantly variable data. The data in Table- 1 showed that higher $\left(550 \mathrm{~g} \mathrm{~m}^{-2}\right)$ dry biomass was recorded for Swabi area than Haripur (478 $\mathrm{g} \mathrm{m}^{-2}$ ). Among the competitive plants sorghum, buffel grass, millet and maize strongly suppressed the growth of parthenium weed, while the rest of the test species showed less competition. The highest $\left(770.25 \mathrm{~g} \mathrm{~m}^{-2}\right)$ dry biomass was observed for sorghum that was statistical at par with millet $\left(722.39 \mathrm{~g} \mathrm{~m}^{-2}\right)$ and the minimum (463.74 $\mathrm{g} \mathrm{m}^{-2}$ ) biomass was noted in mung bean sown plots (Table1). Sorghum, buffel grass, maize and millet suppressed the growth of Parthenium weed by $84.7,77.7,74.4$ and $66.9 \%$ respectively as comared to check (Figure-1). The competitive plants mung bean and moth bean showed 47.2 and $40.5 \%$ reduction in parthenium dry biomass. In case of interaction between locations and competitive plants the highest $\left(834.20 \mathrm{~g} \mathrm{~m}^{-2}\right)$ dry biomass was noted for sorghum $x$ Swabi and the lowest (419.3 $\mathrm{g} \mathrm{m}^{-2}$ ) dry biomass found for mung bean $x$ Haripur. The ability of these plant species in the field to suppress the parthenium weed growth and reduce its dry biomass may be due to favorable environmental conditions and some physiological characteristics of these plants 
species as better competitors with parthenium weed. Some plant species have characteristically produce a broad root system, fast growth pattern, have a good tillering ability and leaf canopy quite early after emergence from the soil, hence an early space capture. Our findings are in agreement with those of Bowen et al. (2007). Sorghum (Sorghum bicolor L.) and maize (Zea mays L.) cultivated crops have also been shown to significantly suppress growth of parthenium weed in the field (Singh 1993). Pakistani native grasses such as slender buffel grass (Cenchrus pennisetiformis Hochst. \& Steud.) and Johnson grass (Sorghum halepense L. Pers.) have all been reported to be good at suppressing parthenium weed growth in rangelands (Anjum and Bajwa 2005; Javaid et al. 2005). These plants were able to extract water and nutrients more efficiently than parthenium weed. These observations are also in accordance with the findings by O'Donnell and Adkins (2005) where it was reported that a number of improved, introduced plant species were able to displace parthenium weed in a glasshouse study. These plants may inhibit the growth of parthenium weed through competition or through an allelopathic interference (Khan et al. 2013). These features of faster growth or interference may be the characteristics of these species that makes them useful for the displacement of parthenium weed.

Table 1. Plants shoot dry biomass production $\left(\mathrm{g} \mathrm{m}^{-2}\right)$ at field sites of Swabi and Haripur, Pakistan.

\begin{tabular}{llll}
\hline & \multicolumn{2}{c}{ Locations } & \\
\cline { 2 - 4 } Competitive plants & Swabi & Haripur & Means \\
\hline Sorghum & 834.20 & 706.3 & $770.25 \mathrm{a}$ \\
Buffel grass & 625.28 & 516.1 & $570.69 \mathrm{~b}$ \\
Millet & 805.20 & 639.6 & $722.39 \mathrm{a}$ \\
Maize & 584.20 & 625.2 & $604.70 \mathrm{~b}$ \\
Mung bean & 507.98 & 419.5 & $463.74 \mathrm{c}$ \\
Moth bean & 494.40 & 443.3 & $468.83 \mathrm{c}$ \\
$\begin{array}{l}\text { Means } \\
\text { LSD (0.05) for test competitive crops dry biomass: 51.226 }\end{array}$ & $478.56 \mathrm{~b}$ & \\
$\begin{array}{l}\text { LSD (0.05) for location: } 27.382 \\
\text { LSD (0.05) for competitive plant dry biomass x locations: } 72.445\end{array}$ &
\end{tabular}


Parthenium Dry Biomass $\left(\mathrm{g} \mathrm{m}^{-2}\right)$

The results of the present study showed that the location, competitive plants and their interaction all significantly affected the growth of partheinum weed in terms of dry biomass reduction. The parthenium weed growth were greatly suppressed in the Swabi area where only $257.20 \mathrm{~g} \mathrm{~m}^{-2}$ dry biomass of parthenium was noted, while in Haripur area $264.18 \mathrm{~g} \mathrm{~m}^{-2}$ parthenium dry biomass was recorded (Table-2). The means of the competitive plants showed that the minimum $95.01 \mathrm{~g} \mathrm{~m}^{-2}$ dry biomass of parthenium was recorded in the plots sown with sorghum and the higher $362.63 \mathrm{~g} \mathrm{~m}^{-2}$ dry biomass of parthenium was noted in moth bean sown plants. The interaction of competitive plants and studied location showed that the minimum $(94.58 \mathrm{~g}$ $\mathrm{m}^{-2}$ ) dry biomass of parthenium was noted for sorghum $\mathrm{x}$ Haripur and the maximum (394.33 $\mathrm{g} \mathrm{m}^{-2}$ ) dry biomass of parthenium was noted for mung bean $\mathrm{x}$ Haripur (Table 2 ). The instant results clearly showed that the used competitive plants species variably suppress the growth of parthenium weed and restrict the parthenium growth. Khan et al. (2014); have found that the fodder species suppressed the growth of $P$. hysterophorus, with Sorghum almum, $C$. ciliaris and $C$. gayana suppressing growth by $>73 \%$ and producing at least $622 \mathrm{~g} \mathrm{~m}^{-2}$ of dry fodder biomass.

The best performing test species growing into highly infested with $P$. hysterophorus land was sorghum species which suppressed the growth of $P$. hysterophorus by more than $80 \%$ compared with control plot and was effective over both field sites (Fig. 2)., In addition, buffel grass produced $>570 \mathrm{~g} \mathrm{~m}^{-2}$ dry shoot biomass, suppressed the growth of $P$. hysterophorus by $>77 \%$ (Fig. 2). The Swabi site was better than Haripur in terms of parthenium biomass reduction probably due to its warmer climatic condition that promoted the growth of competitive plants than Haripur site that having comparative cooler climatic conditions. Morover the Swabi site had a good soil conditions and irrigated land suitable for these competitive plants production that ultimately suppressed the growth of parthenium weed. Kandasamy and Sankaran (1997) have found that field crops (viz. maize, Zea mays L.; sorghum, Sorghum bicolor L.; and sunflower, Helienthus annuus) that formed canopies early that effectively suppressed the population and biomass of parthenium weed. 
Table-2: $\quad$ Parthenium shoot dry biomass production $\left(\mathrm{g} \mathrm{m}^{-2}\right)$ at field sites of Swabi and Haripur, Pakistan.

\begin{tabular}{llll}
\hline & \multicolumn{2}{c}{ Locations } & Means \\
\cline { 2 - 4 } Competitive plants & Swabi & Haripur & $95.01 \mathrm{~d}$ \\
\hline Sorghum & 95.45 & 94.58 & $124.96 \mathrm{~d}$ \\
Buffel grass & 112.60 & 137.33 & $177.53 \mathrm{c}$ \\
Millet & 151.33 & 203.73 & $192.18 \mathrm{c}$ \\
Maize & 226.32 & 158.03 & $348.16 \mathrm{a}$ \\
Mung bean & 302.00 & 394.33 & $362.63 \mathrm{a}$ \\
Moth bean & 340.45 & 384.80 & \\
Means & $257.20 \mathrm{~b}$ & $264.18 \mathrm{a}$ &
\end{tabular}

LSD (0.05) for parthenium weed dry biomass: 39.013

LSD (0.05) for locations: 20.853

LSD (0.05) for parthenium weed dry x locations : 55.173

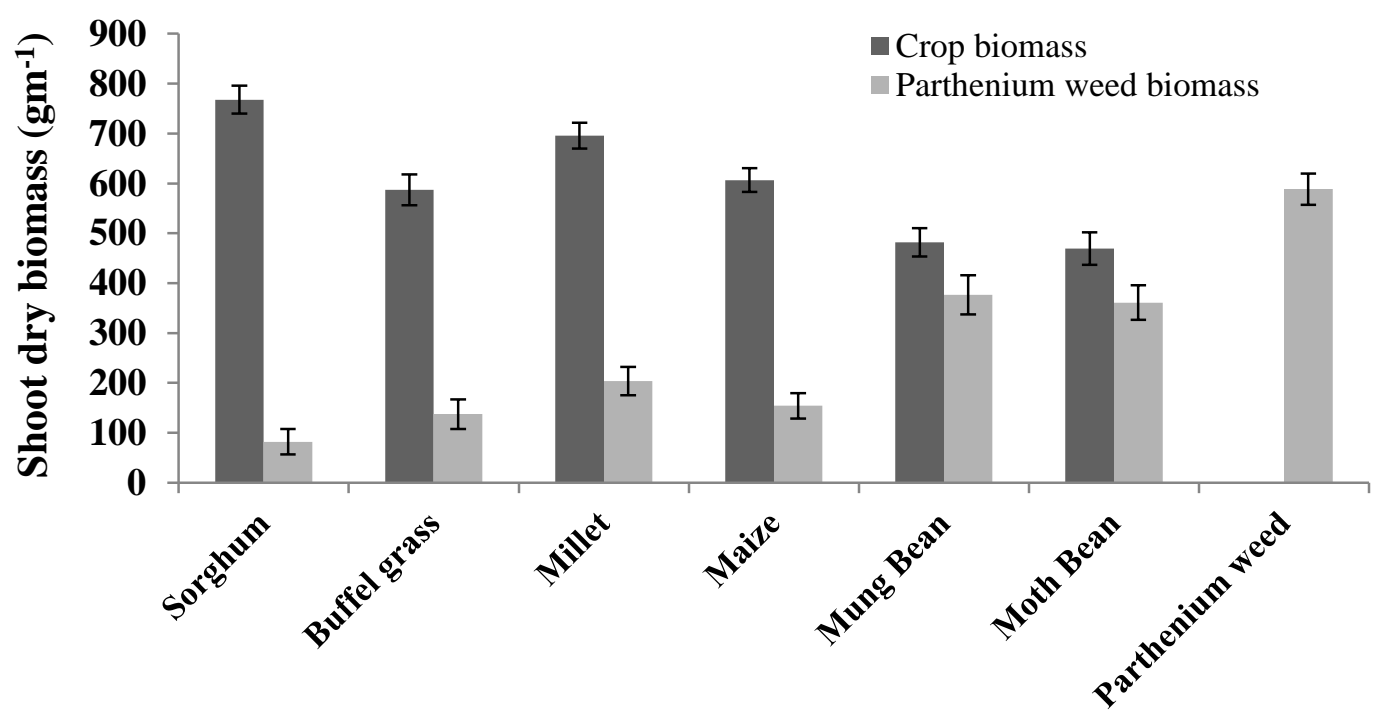

Figure 1. Dry biomass of competitive plants and parthenium weed at the Swabi field. The data sets are the means \pm standard error for measurements taken from four replicate plots. 


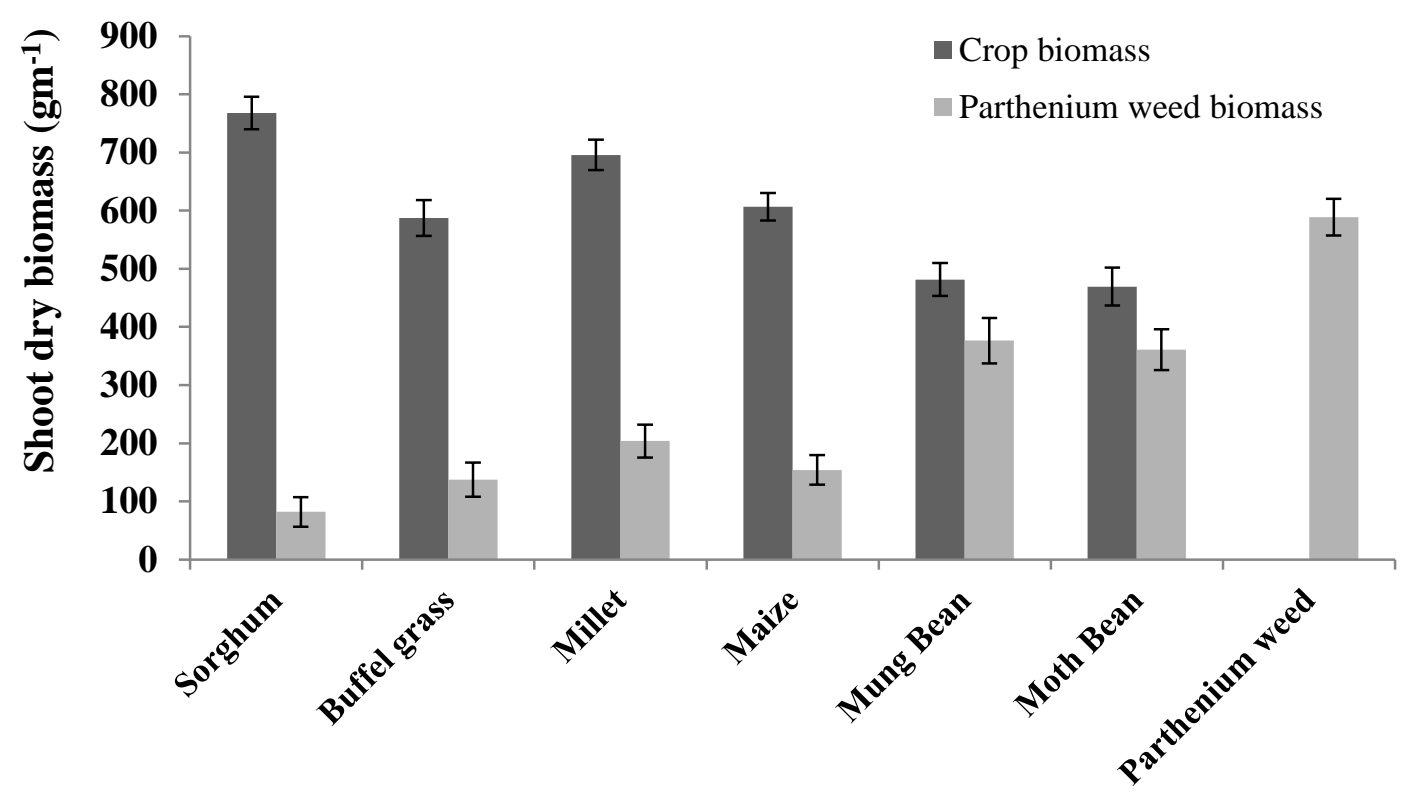

Figure 2. Dry biomass of competitive plants and parthenium weed at the Haripur field site. The data sets are the means \pm standard error for measurements taken from four replicate plots.

\section{CONCLUSION AND RECOMMENDATIONS}

The four crops such as sorghum, buffel grass, maize and millet suppressed the parthenium growth and reduced its dry biomass $>60 \%$ and produced high dry biomasses at both the studied sites. The legumes i.e. mung bean and moth bean were found less suppressive to the parthenium weed and gave lesser amount of dry biomass. Moreover, the competitive ability of parthenium with other plants were climatic dependent as this weed poorly competed with the tested plants in the warmer climatic conditions than the cooler one. Further field studies are needed to check other suppressive plants and test these species under varying agro-ecological conditions to manage the invasive parthenium weed.

\section{REFERENCES}

Adkins S.W., Navie, S.C. \& McFadyen, R.E. (1996). Control of parthenium weed (Parthenium hysterophorus L.): A Centre for Tropical Pest Management team effort. In Proceedings of the $11^{\text {th }}$ Australian Weeds Conference, ed. R.C.H. Shepherd, p. 573-578. Weed Science Society of Victoria, Frankston, 30 September-3 October, 1996. 
Anjum, T. \& Bajwa, R. (2005). Importance of germination indices in interpretation of allelochemical effect on seed germination. International Journal of Agriculture and Biology 7(3): 417-419.

Bowen, D., Ji, J. \& Adkins, S. (2007). Management of parthenium weed through competitive displacement with beneficial plants: a field study, Brisbane. A report to the Queensland Murray Darling Committee, pp 1-16. The University of Queensland.

Javaid, A., Tehmina, A. \& Bajwa, R. (2005). Biological control of parthenium II: Allelopathic effect of Desmosta chyabipinnata on distribution and early seedling growth of Parthenium hysterophorus L. International Journal of Biology and Biotechnology 2: 459-463.

Kandasamy, O.S. \& Sankaran, S. (1997). Biological suppression of parthenium weed using competitive crops and plants. Proceedings of the First International Conference on Parthenium Weed Management, University of Agricultural Sciences, Darwad, India, pp 33-6

Khan, N., O’Donnell, C., George, D. \& Adkins, S.W. (2013). Suppressive ability of selected fodder plants on the growth of Parthenium hysterophorus. Weed Research 53: 61-68.

Khan, N., Shabbir, A., George, D., Hassan, G. \& Adkins, S.W. (2014). Suppressive fodder plants as part of an integrated management program for Parthenium hysterophorus L. Field Crop Research 159: 172-179.

Khosla, S.N. \& Sobti, S.N. (1979). Parthenium a national health hazard, its control and utility a review. Pesticides 13: 121-127.

Lakshmi, C. \& Srinivas, C. (2007). Type I hypersensitivity to Parthenium hysterophorus L. in patients with parthenium dermatitis. Indian Journal of Dermatology, Venereology and Leprology 73: 103105.

Navie, S.C., Panetta, F.D., McFadyen, R.E. \& Adkins, S.W. (1996). The biology of Australian weeds, Parthenium hysterophorous L. Plant Protection 11: 76-88.

O’Donnell, C. \& Adkins. S.W. (2005). Management of parthenium weed through competitive displacement with beneficial plants. Weed Biology and Management 5: 77-79.

Parson, W.T. \& Cuthbertson, E.G. (1992). Noxious weeds of Australia, Inkata Press, Australia.

Riaz, T. \& Javaid, A. (2011). Prevalence of alien weed Parthenium hysterophorus in grazing and wastelands of district Attock, Pakistan. Journal of Animal and Plant Science 21: 542-545.

Shabbir, A. \& Bajwa, R. (2006). Distribution of parthenium weed (Parthenium hysterophorus L.), an alien invasive weed species threatening the biodiversity of Islamabad. Weed Biology and Management 6: 89-95. 
Shabbir, A., Dhileepan, K. \& Adkins, S.W. (2012). Spread of parthenium weed and its biological control agent in the Punjab, Pakistan. Pakistan Journal of Weed Science Research 18: 581588.

Singh, S.P. (1993). Integrated management of parthenium. Integrated weed management for sustainable agriculture. In Proceedings of an Indian Society of Weed Science International Symposium, p.393-108, Hisar, India, 18-20 November, 1993.

Steel, R.G.D. \& Torrie, J.H. (1980). Principles and Procedures of Statistics: A Biometrical Approach. McGraw Hill Inc., USA.

Tamado, T., Ohlander, L. \& Milberg, P. (2002). Interference by the weed Parthenium hysterophorus L. with grain sorghum: Influence of weed density and duration of competition.
International Journal of Pest Management 48: 183-188.

Wahab, S. (2005). Management of parthenium weed through an integrated approach initiatives, achievements and research opportunities in India. In Proceedings of the Second International Conference on Parthenium Management, eds. T.V.R. Prasad, H.V. Nanjappa, R. Devendra, A. Manjunath, Subramanya, S.C. Chandrashekar, V.K.K. Kumar, K.A. Jayaram and T.K.P. Setty, p. 127-333. Bangalore, 5-7 December 2005.

Williams, J.D. \& Groves, R.H. (1980). The influence of temperature and photoperiod on growth and development of Parthenium hysterophorus L. Weed Research 20: 47-52. 